\title{
Reading in The Digital Age: Electronic Storybook as a Teaching Tool for Beginning Readers
}

\author{
Khusnul Khotimah, Ady Achmad Ali Wahyu \\ Department of Educational Technology \\ Universitas Negeri Surabaya \\ Surabaya, Indonesia \\ khusnulkhotimah@unesa.ac.id
}

\begin{abstract}
The purpose of this study is to develop electronic storybook and use it in elementary school students. The material is about the rights and obligations of the civic education course for fifth-grade Elementary School. This study using the R \& D model. Data collection techniques using questionnaires, interviews, and tests to determine the media feasibility, and the level of effectiveness using the t-test. The trial was carried out on material and media experts and also the students. The results of the media feasibility test are categorized very well, meaning that electronic storybook is feasible to be applied in learning. Then the book has been applied and students are given a pretest and post-test. The post-test results were higher than the pre-test results. Based on the analysis data it can be concluded that $t$ count is greater than $t$ table. So, there is a significant difference between the pre-test and post-test and it is stated that electronic storybooks significantly improve student motivation in reading and their learning outcomes.
\end{abstract}

Keywords—beginning readers; digital technologies; electronic storybook; a teaching tool

\section{INTRODUCTION}

Reading is such an effortful activity. Motivation is a factor in whether children choose to devote their energy to such a task [1]. Motivation theorists attempt to understand the choices that individuals make among different activities available to them and their effort and persistence at the activities they choose [2]. Even the reader with the strongest cognitive skills may not spend much time reading if he or she is not motivated enough to read. Students who do not master reading skills early in their school years, reading may become a painful experience. As a result, they may decline opportunities for practice, putting themselves even further behind successful [3].

Learning to read proficiently in the primary grades is one of the cornerstones of academic achievement and the foundation for children's later success in school [4]. Beginning readers' motivation to read and the texts they choose to read impact on their literacy achievement and willingness to engage with reading activities in the primary years of schooling [5]. Children who successfully learn to read in the early primary years of school are well prepared to read for learning and for pleasure in the years to come. Thus, it becomes a big challenge for elementary school teachers to make reading a favorite for all children.
That's why the importance of reading undertaken in elementary school cannot be underestimated. It is important that young people develop reading skills as early as possible [6]. Young people nowadays are often more comfortable sitting in front of a computer surfing the web than they are sitting reading a book, with the suggestion being made that readers no longer have the concentration to read articles through to their conclusion [7]. As a result of the decreasing interest in reading and the growing appeal of computers, it has been suggested that the electronic environment is becoming more important to the growing number of children who do not respond well to traditional print media and who are reluctant to read. New technologies are now in existence which could change the way children read [6].

The progress in digital technologies is dramatically altering all the tools available to teachers and students. These technological advances have created excitement among many for their potential to be used as instructional tools for literacy education [8]. The emergence of the first digital book in Indonesia in 1998 continued to move the books writer and other publishers to join as well as selling his works in versions digital. Until now, digital book publishers are also increasing. There are 6 largest digital book publishers, based on the 2014 bestseller list, Random House Penguin, Harper Collins, Hachette, Amazon Publishing, Simon \& Schuster, Slf Publishing [9]. Along with it, since 2007, the number of devices available for displaying digital text has increased exponentially [8]. These technological advances have created high hopes among many teachers, administrators, researchers, and policymakers, who believe that digital devices offer great promise as instructional tools for literacy education.

Without the availability of technology, students with reading difficulties must overcome sub-standard barriers imposed by printed materials they are asked to read. Technology can help students to overcome these challenges by enabling a shift from printed text to electronic text. By electronic text, we mean textual material read using a computer or some other electronic device such as a Palm, iPod, or even a Leap Pad. Shifting to a computer for presenting text offers immediate advantages to readers, primarily cause a computer can be used to modify the way text is viewed and read: face font, size, and color can be changed; text can be read out loud; concepts can be defined and explained; simultaneous multiple illustrations; links can lead to supportive formation; and 
documents can be accessed from different computers in different geographic locations. In short, electronic texts are malleable [10]. Technology can be more than a tool for drilling students on skills; it can be a tool for acquiring the vocabulary and background knowledge essential to becoming a skilled reader.

Well-designed technology-enhanced books may be particularly suited to improve learning conditions for vulnerable children and turn putative risk groups into successful learners [11]. Media-specific design features such as video and interactivity may make 'independent e-book reading' a valuable tool to promote early language and literacy development [12]. Electronic storybooks can improve reading comprehension and can be beneficial for struggling readers [13]. The development and use of a digital tool such as electronic storybook to promote learning outcome in classroom contexts is the focus of the research described in this article.

\section{METHOD}

\section{A. Research Design}

Development is the process of translating design specifications into the physical form [14]. According to this definition, development is defined as the process of making a product that has certain specifications into a real physical form. educational research and development is a process used to develop and validate educational products, meaning that education development research (R\&D). The results of development research are not only the development of an existing product but also to find knowledge or answers to practical problems [15].

The development model used is the Research and Development (R \& D) model. As for the steps are as follows:

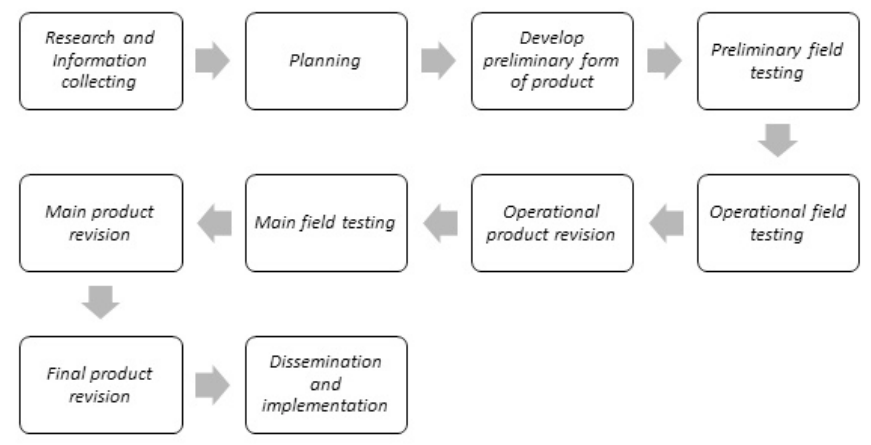

Fig. 1. Research and Development Model by Borg and Gall

As illustrated in figure 1 that there are ten stages of research development as follows: (1) Research and information collecting, (2) Planning, (3) Develop preliminary form of product, (4) Preliminary field testing, (5) Operational field testing, (6) Operational product revision, (7) Main field testing, (8) Main product revision, (9) Final product revision, (10) Dissemination and implementation [15].

\section{B. Research Subject}

The subjects of this study were the 5th-grade students of Sungonlegowo public elementary school in Gresik Regency is a regency within the East Java Province of Indonesia. The average student is 11-12 years old and there are 34 students. Other than that, as a research subject, there were media expert and material expert about rights and obligations on subjects of citizenship education from Surabaya State University.

\section{Data Collection Technique}

Data collected in the form of qualitative and quantitative. Data collection techniques using questionnaires, interviews, and tests to determine the feasibility of an electronic storybook.

\section{Data Analysis Technique}

Data analysis use descriptive data analysis techniques, namely by describing the validity and effectiveness of the development.

\section{RESUlTS AND DisCUSSION}

\section{A. Research and Information Collecting}

This first step includes needs analysis, literature study, literature study, small scale research. The literature study was conducted for a temporary introduction to the product to be developed, and this was done to gather research findings and other information related to planned product development. While small-scale research is conducted so that researchers know several things about the product to be developed.

From the observations at the research location, information was obtained that there was material that is difficult for students to understand. The material is about rights and obligations in civic education subjects. Students are also less motivated to read ordinary textbooks that have only written and are not colored. Reading is not their favorite activity, and books are not interesting to read. The average score for this subject is still below the standard number 75 , which is between $60-70$.

\section{B. Planning}

After obtaining complete information and data about the existing problems, researchers conducted a study of the characteristics of students who were the object of research. The characteristics found are:

- Students love learning while playing.

- Students like learning that gives rise to activities.

- Students are very interested and active when learning by using media.

- Students are already familiar with digital technology, even $80 \%$ of students already have sophisticated mobile phones.

The aim of this study is to develop media that matches the characteristics of students and material and use them in the 
learning process. Researchers have determined that suitable media is in the form of electronic storybooks. Then researchers began to make plans for the manufacture of electronic storybooks.

\section{Develop Preliminary Form Of Product}

Electronic storybook developed in the form of applications that can be operated on the Android operating system. Contains stories that match predetermined content, colorful and pictures, there are interesting characters, characters in the story are made close to children, accompanied by background music and also practice questions. This media contains the following matters:

- Learning objectives

- An illustrated story about the implementation of obligations and rights in everyday life

- Colored cartoon with background music and sound effects.

- Questions / quizzes

\section{Preliminary Field Testing}

The next step is the prototype validation. The validator is an expert in civic education lessons and an expert in the field of learning media. Data was collected using a questionnaire instrument. The results of data analysis obtained from material experts are very good with a percentage of $100 \%$. The results of data analysis obtained from media experts are also in the very good category with a percentage of $95 \%$.

In addition to expert testing, at this stage also conducted tests on students called individual tests. The media was tested on three students with high, medium and low ability levels. The percentage of results obtained was $88.88 \%$, meaning that the media included in the category of Very Good.

\section{E. Operational Field Testing}

At this stage, the test was conducted on 6 student respondents. Respondents were taken randomly consisting of 2 girls and 4 boys. The results of data analysis in this test obtained a percentage of $90.74 \%$, this percentage shows that the media are included in the category of Very Good.

\section{F. Operational Product Revision}

Product revisions made at this stage are on the following matters:

- Additional background music

- Additional sound effects

- Numbering on each page

- Writing conversational sentences in quotation marks

- Practice questions are equipped with an automatic score

- Improved text color

\section{G. Main Field Testing}

After the product revision is complete, then the field test is carried out. This stage was tested with 25 student respondents. At this stage, pretest and post-test are conducted and the results are measured using a t-test. Usage test results are used to determine student learning outcomes before and after using media. Based on the data obtained a percentage of $92.88 \%$, this percentage shows that the media are included in the category of Very Good.

\section{H. Main Product Revision}

Improvements were made to the media based on main field testing results.

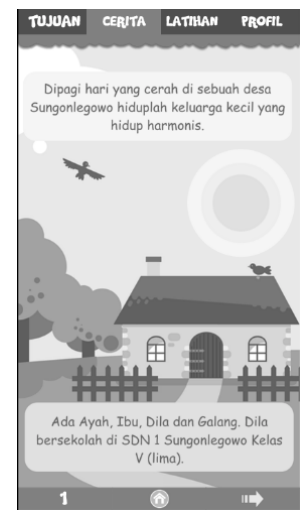

Fig. 2. Main Product Revision

Figure 2 illustrates the result of one of the improvements. The revisions made are as follows:

- Improvements to the color of the text are made more attractive.

- Clarity of the sentence in the story

\section{Final Product Revision}

Improvements were made to the media based on all testing results.

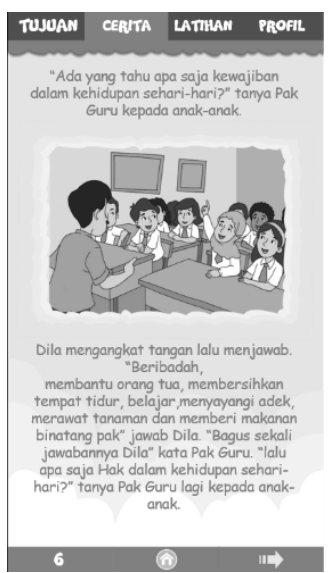

Fig. 3. Final Product Revision

Figure 3 illustrates the result of one of the improvements. The revisions made are as follows: 
- Improvements to the color of the background are made more varied.

- Clarity of sentence in the story.

The improvement of the final product is done so that the developed media is more accurate. At this stage, an electronic storybook has been obtained for which the level of effectiveness can be accounted for.

\section{J. Dissemination and Implementation}

Products are disseminated at professional forums and implemented in educational practice. Currently, electronic storybooks have been used at the school where the research was conducted.

\section{CONCLUSION}

The decrease in motivation to read across the elementary school years has stimulated concern about how students might be motivated to read and engage in literacy activities. This study has shown that digital technology can promote reading motivation among beginning readers. This study also shows that increased reading motivation has an effect on material understanding and learning outcomes. Researchers suggest that educators and parents are being instrumental in helping their students to develop the new skills and strategies that are important in today's technological age.

Overall, the findings from this study have shown that the electronic storybook has been very satisfying as a substitute for printed books, and can also be a beneficial supplement for oral and print literacy for 5 th-grade students. These digital media may provide an opportunity for practice of skills that beginning readers learn from direct, systematic instruction in their classrooms, in a highly appealing and constructivist manner.

\section{REFERENCES}

[1] A. Wigfield, J. T. Guthrie, S. Tonks, and K. C. Perencevich, "Children's motivation for reading: Domain specificity and instructional influences," J. Educ. Res., vol. 97, no. 6, pp. 299-310, 2004.
[2] D. H. Schunk, J. R. Meece, and P. R. Pintrich, Motivation in education: Theory, research, and applications. Pearson Higher Ed, 2012.

[3] A. Taboada, S. M. Tonks, A. Wigfield, and J. T. Guthrie, "Effects of motivational and cognitive variables on reading comprehension," Read. Writ., vol. 22, no. 1, p. 85, 2009.

[4] L. T. Strommen and B. F. Mates, "Learning to love reading: Interviews with older children and teens," J. Adolesc. Adult Lit., vol. 48, no. 3, pp. 188-200, 2004.

[5] K. Ciampa, "Reading in the digital age: Using electronic books as a teaching tool for beginning readers.," Can. J. Learn. Technol., vol. 38 , no. 2, p. n2, 2012.

[6] S. Maynard, "The impact of e-books on young children's reading habits," Publ. Res. Q., vol. 26, no. 4, pp. 236-248, 2010.

[7] P. Kingsley, "The art of slow reading," Guard., vol. 15, 2010.

[8] G. Biancarosa and G. G. Griffiths, "Technology tools to support reading in the digital age," Futur. Child., vol. 22, no. 2, pp. 139-160, 2012.

[9] D. Nurbaiti, "Perkembangan Ebook Dalam Industri Penerbitan Buku Fisik Serta Pertumbuhan Minat Menulis Buku," Ikra-Ith Ekon., vol. 2, no. 2, pp. 11-20, 2019.

[10] L. ANDERSON-INMAN and M. A. Horney, "Supported eText: Assistive technology through text transformations," Read. Res. Q., vol. 42 , no. 1 , pp. 153-160, 2007

[11] A. G. Bus, Z. K. Takacs, and C. A. T. Kegel, "Affordances and limitations of electronic storybooks for young children's emergent literacy," Dev. Rev., vol. 35, pp. 79-97, 2015.

[12] D. J. H. Smeets, "Storybook apps as a tool for early literacy development." 2012.

[13] I. S. Ertem, "The Effect of Electronic Storybooks on Struggling FourthGraders' Reading Comprehension.," Turkish Online J. Educ. Technol., vol. 9, no. 4, pp. 140-155, 2010.

[14] B. B. Seels and R. C. Richey, Instructional technology: The definition and domains of the field. IAP, 2012.

[15] W. Borg, "R, Meredith D. Gall. 2003," Educ. Res. An Introd. Seven Ed. Boston. New York, San Francisco, 2013. 